\title{
CBX3 wt Allele
}

National Cancer Institute

\section{Source}

National Cancer Institute. CBX3 wt Allele. NCI Thesaurus. Code C73634.

Human CBX3 wt allele is located in the vicinity of 7p15.2 and is approximately $12 \mathrm{~kb}$ in length. This allele, which encodes chromobox protein homolog 3 , is involved in epigenetic repression of chromatin, control of gene expression and association of heterochromatin with the inner nuclear membrane. 